\title{
High temperature syntheses of novel nitrido- and oxonitrido-silicates and sialons using rf furnaces $\uparrow$
}

\author{
Wolfgang Schnick, $*$ Hubert Huppertz $\$$ and Rainer Lauterbach \\ Laboratorium für Anorganische Chemie der Universität, D-95440 Bayreuth, Germany
}

Received 8th March 1998, Accepted 26th May 1998

\begin{abstract}
The high-temperature reaction of pure metals with silicon diimide $\mathrm{Si}(\mathrm{NH})_{2}$ in a specially developed radiofrequency furnace has been successfully applied to the synthesis of novel highly condensed nitridosilicates. With $\mathrm{SrCO}_{3}$ as an additional starting material this procedure has now been extended to the synthesis of oxonitridosilicates and oxonitridoaluminosilicates (sialons). Two novel sialons $\mathrm{SrSiAl}_{2} \mathrm{O}_{3} \mathrm{~N}_{2}$ [space group $P 2_{1} 2_{1} 2_{1}$ (no. 19), $a=491.89(6)$, $b=789.73(7), c=1134.94(18) \mathrm{pm}, Z=4$ ] and $\mathrm{SrErSiAl}_{3} \mathrm{O}_{3} \mathrm{~N}_{4}$ [space group $P 6_{3} m c$ (no. 186), $a=606.53(3), c=$ 985.90(8) pm, $Z=2$ ] have been obtained as coarsely crystalline materials. According to single crystal X-ray diffraction both compounds adopt structure types which are unprecedented for sialons. They derive from the nitridosilicates $\mathrm{LnSi}_{3} \mathrm{~N}_{5}(\mathrm{Ln}=\mathrm{La}, \mathrm{Ce}, \mathrm{Pr}, \mathrm{Nd})$ and $\mathrm{MYbSi}_{4} \mathrm{~N}_{7}(\mathrm{M}=\mathrm{Sr}, \mathrm{Ba}, \mathrm{Eu})$, respectively, by partial substitution of Si by $\mathrm{Al}$ and $\mathrm{N}$ by $\mathrm{O}$. For $\mathrm{SrSiAl}_{2} \mathrm{O}_{3} \mathrm{~N}_{2}$ and $\mathrm{SrErSiAl}_{3} \mathrm{O}_{3} \mathrm{~N}_{4}$ an unambiguous crystallographic differentiation between the tetrahedral centres $(\mathrm{Al}$ and $\mathrm{Si})$ as well as the bridging atoms of the framework structures $(\mathrm{N}$ and $\mathrm{O})$ seems reasonable.
\end{abstract}

\section{Introduction}

Polymeric nonmetal nitrides are of considerable interest for the development of inorganic materials for high-performance applications. ${ }^{1,2}$ Among the binary members of this class of compounds cubic and hexagonal boron nitride ( $\mathrm{BN}$ ) as well as silicon nitride $\left(\mathrm{Si}_{3} \mathrm{~N}_{4}\right)$ increasingly have gained relevance. Practical applications include substrates for semiconductors on the basis of $\mathrm{Si}_{3} \mathrm{~N}_{4}$ or high-temperature materials like valve tappets and turbochargers $\left(\mathrm{Si}_{3} \mathrm{~N}_{4}\right)$ or crucibles made of hexagonal BN. ${ }^{1}$

The binary compounds $\mathrm{BN}$ and $\mathrm{Si}_{3} \mathrm{~N}_{4}$ are well known since the last century. However both have not been used as starting materials for the synthesis of multinary nonmetal nitrides. A varied chemistry comparable to that of oxidic borates, silicates, or phosphates, which derives by formal exchange of oxygen by nitrogen, has not been established until recently.,3 However, the numerous oxidic silicates and phosphates, which include the clay minerals or the framework structures of zeolites illustrate the demand for multinary compounds in order to design tailormade materials.

The most important reason for the lack of knowledge concerning multinary nitridosilicates was the high chemical and thermal stability of the binary nitride $\mathrm{Si}_{3} \mathrm{~N}_{4}$. On one hand this inertness is an important precondition for an application of $\mathrm{Si}_{3} \mathrm{~N}_{4}$ in high-temperature and high-performance devices. On the other hand this property seems to rule out the usage of $\mathrm{Si}_{3} \mathrm{~N}_{4}$ as a starting material in chemical reactions.

Oxidic silicates are accessible by high-temperature reactions of silica $\left(\mathrm{SiO}_{2}\right)$ with metal oxides or carbonates. However an analogous broad synthetic approach seems to be difficult for nitridosilicates. And even the hydrothermal method, which represents an important synthetic tool for the preparation of oxidic zeolites, could not be adapted and modified to an analogous ammonothermal route yielding nitridosilicates.

For these reasons we have developed a novel synthetic

$\dagger$ Basis of the presentation given at Materials Chemistry Discussion No. 1, 24-26 September 1998, ICMCB, University of Bordeaux, France.

\$Present address: Institut für Anorganische Chemie, LudwigMaximilians-Universität München, Meiserstr. 1, D-80333 München, Germany. approach leading to ternary and multinary nitridosilicates by high-temperature reactions of pure metals with silicon diimide. ${ }^{3,4}$ With this broad synthetic access several novel nitridosilicates have been obtained and they have been characterised. Highly condensed network structures of corner-sharing $\mathrm{SiN}_{4}$ tetrahedra occur in the alkaline-earth compounds $\mathrm{M}_{2} \mathrm{Si}_{5} \mathrm{~N}_{8}$ with $\mathrm{M}=\mathrm{Ca}, \mathrm{Sr}$, or $\mathrm{Ba}^{4,5}$ or the rare-earth compounds ${ }^{6,7}$ $\mathrm{M}_{3}^{\prime} \mathrm{Si}_{6} \mathrm{~N}_{11}$ with $\mathrm{M}^{\prime}=\mathrm{Ce}$, Pr (Fig. 1). According to their high degree of condensation these $\mathrm{Si}-\mathrm{N}$ network structures have no analogues among the oxosilicates.

A simple measure for the degree of condensation in both oxo- and nitridosilicates, which are built up by connected $\mathrm{SiX}_{4}$ tetrahedra $(\mathrm{X}=\mathrm{O}, \mathrm{N})$, is the molar ratio $\mathrm{Si}$ : X. As compared to oxosilicates the degree of condensation may vary in a wider range in the nitridosilicates $(1: 4 \leqslant \mathrm{Si}: \mathrm{N} \leqslant 3: 4)$. In oxosilicates only terminal $\mathrm{O}^{[1]}$ and simply bridging $\mathrm{O}^{[2]}$ occur. $\$$ In accordance with the higher degree of condensation also $\mathrm{N}^{[3]}$ have been found for $\mathrm{Si}: \mathrm{N}>1: 2$ in the nitrido analogues. These $\mathrm{N}^{[3]}$ each are bridging three neighbouring $\mathrm{Si}$ tetrahedral centres. Thus in many nitridosilicates the cross-linking at the $\mathrm{X}$ atoms and the degree of condensation is enhanced as compared to oxosilicates.

Even for a very high molar ratio $\mathrm{Si}: \mathrm{N}$ a further increase of the cross-linking at the nitrogen atoms yielding $\mathrm{N}^{[4]}$ bridges was not expected to be possible, because even in $\mathrm{Si}_{3} \mathrm{~N}_{4}$ this situation does not occur. Surprisingly the quaternary compounds $\mathrm{MYbSi}_{4} \mathrm{~N}_{7}(\mathrm{M}=\mathrm{Sr}, \mathrm{Ba}, \mathrm{Eu})$ exhibit such unusual $\mathrm{N}^{[4]}$ bridges (Fig. 2). ${ }^{8-10}$

In condensed silicates the $\mathrm{SiO}_{4}$ tetrahedra are always connected through common vertices. A unique exception of this rule is the so called 'fibrous' $\mathrm{SiO}_{2}$, which was assumed to be isostructural with $\mathrm{SiS}_{2}$ containing edge-sharing $\mathrm{SiO}_{4}$ tetrahedra. ${ }^{11}$ However the existence and the structure of this compound has not been unequivocally confirmed with modern experimental techniques. In $\mathrm{BaSi}_{7} \mathrm{~N}_{10}$, which is the highest condensed ternary nitridosilicate obtained so far, we identified $\mathrm{SiN}_{4}$ tetrahedra which are connected by both corner-and edgesharing (Fig. 3). ${ }^{12}$ Unlike the situation in oxosilicates, where edge-sharing of $\mathrm{SiO}_{4}$ tetrahedra is unlikely, this phenomenon is more favoured in the nitridosilicates. Apparently, edge-

$\S$ The superscript numbers in square brackets following element symbols define their coordination numbers. 


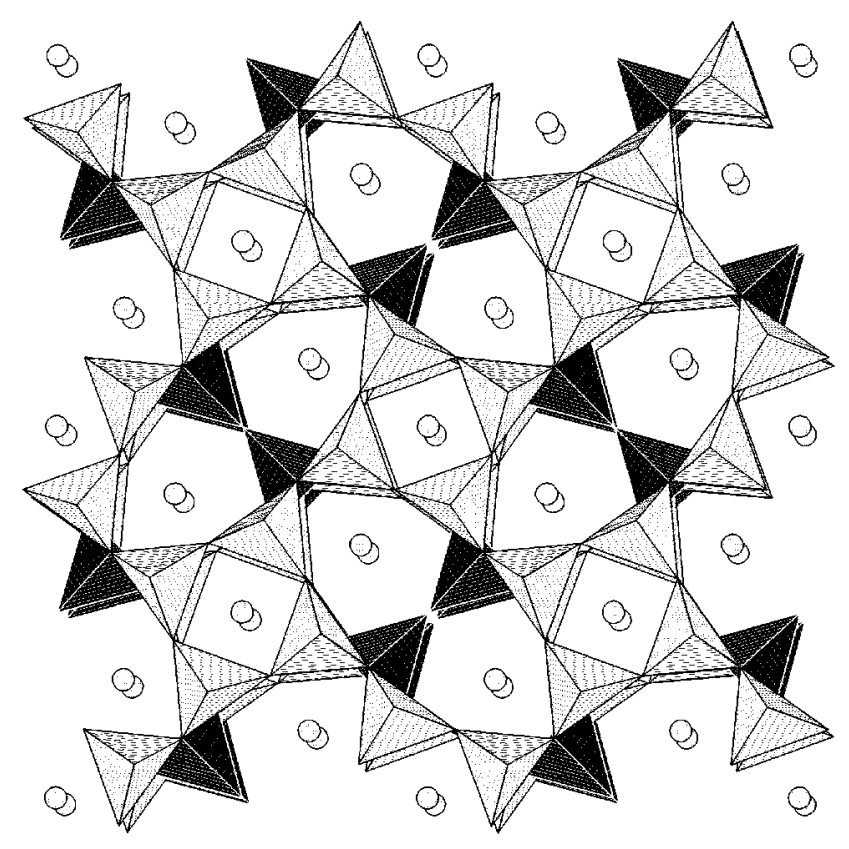

Fig. 1 Crystal structure of $\mathrm{M}_{3}^{\prime} \mathrm{Si}_{6} \mathrm{~N}_{11}\left(\mathrm{M}^{\prime}=\mathrm{Ce}, \mathrm{Pr}\right)$.

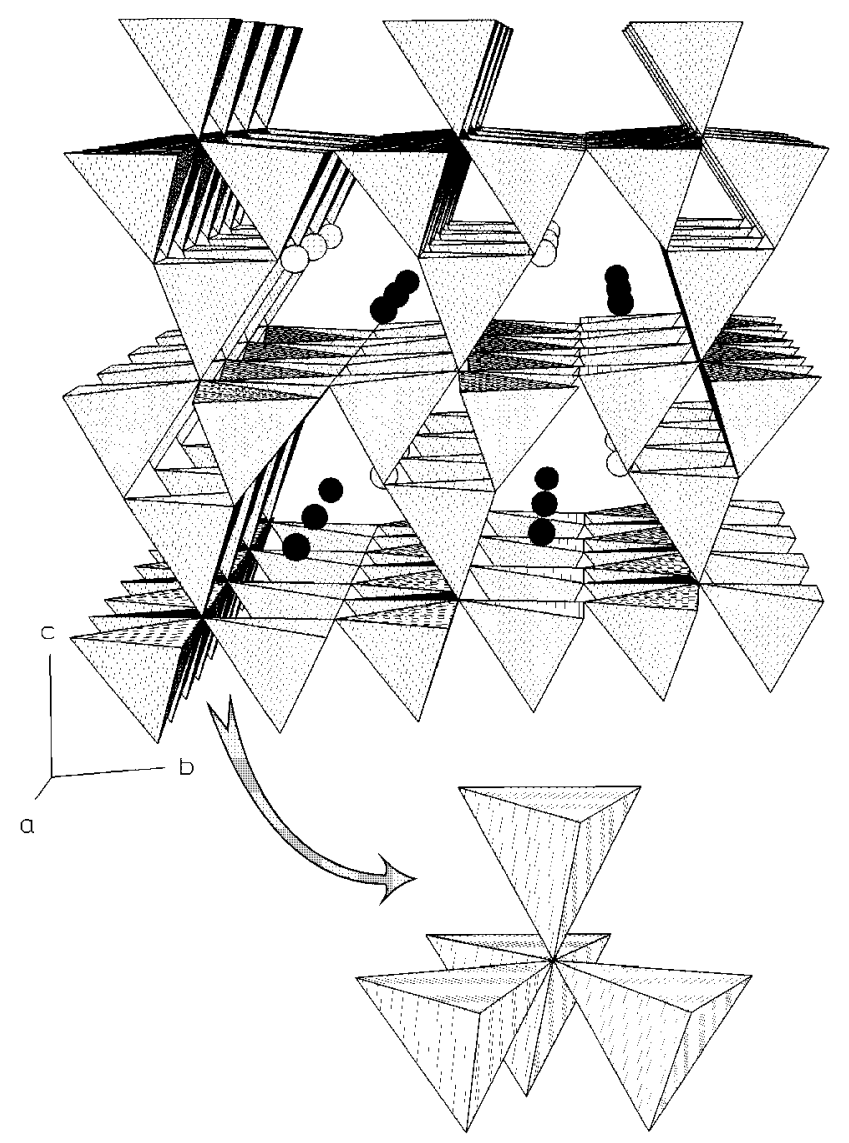

Fig. 2 Crystal structure of $\mathrm{MYbSi}_{4} \mathrm{~N}_{7}(\mathrm{M}=\mathrm{Sr}, \mathrm{Ba}, \mathrm{Eu})$.

sharing of $\mathrm{SiN}_{4}$ tetrahedra occurs independently of the degree of condensation (e.g. $\mathrm{Ba}_{5} \mathrm{Si}_{2} \mathrm{~N}_{6},{ }^{13} \mathrm{BaSi}_{7} \mathrm{~N}_{10}$ ), and edge-sharing does not seem to compete with corner-sharing as both modes coexist in $\mathrm{BaSi}_{7} \mathrm{~N}_{10}$.

All nitridosilicates discussed so far show a very high thermal stability (up to $1600^{\circ} \mathrm{C}$ ) and they are hardly attacked by hot acid or alkali. Presumably this is a direct consequence of the high cross-linking in the $\mathrm{Si}-\mathrm{N}$ network structures and its high covalency. However the question arises, if due to the specific conditions used during their high-temperature syntheses only

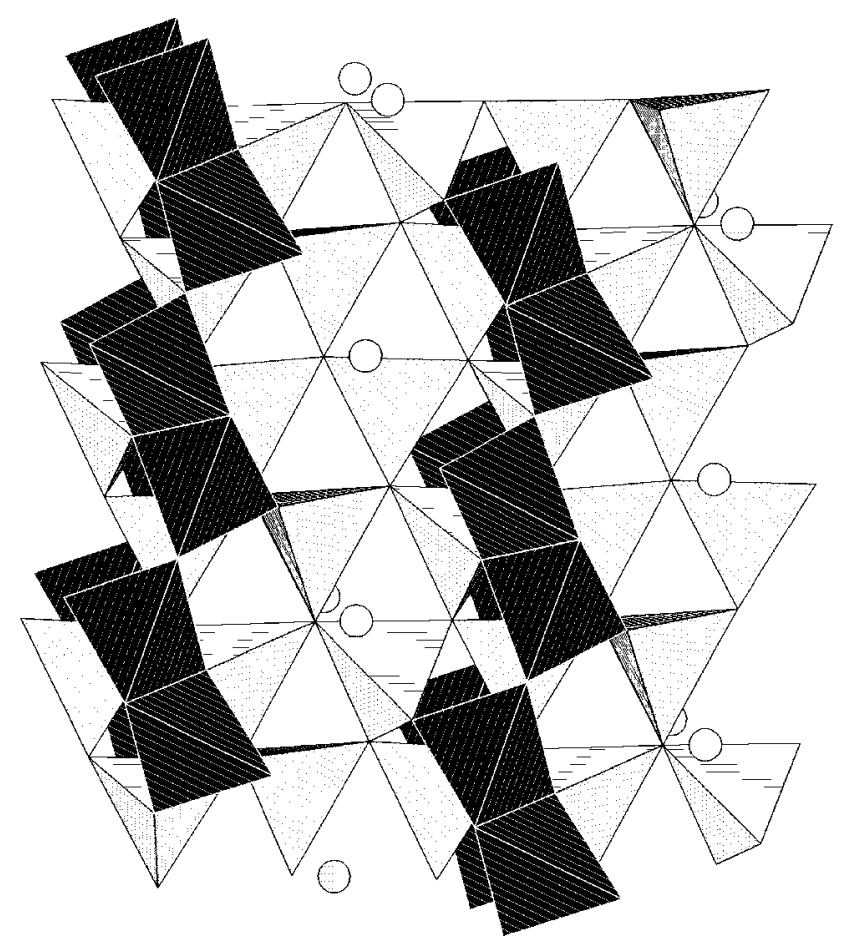

Fig. 3 Crystal structure of $\mathrm{BaSi}_{7} \mathrm{~N}_{10} \cdot \mathrm{SiN}_{4}$ tetrahedra are connected through common edges and vertices.

highly condensed network structures of connected $\mathrm{SiN}_{4}$ tetrahedra are accessible, or if even less condensed network structures might be possible. It seemed to be specifically challenging also to build zeolite-analogous microporous network structures from $\mathrm{SiN}_{4}$ tetrahedra. This was achieved with the synthesis of $\mathrm{Ba}_{2} \mathrm{Nd}_{7} \mathrm{Si}_{11} \mathrm{~N}_{23}$ (Fig. 4). With a molar ratio of $\mathrm{Si}: \mathrm{N}=11: 23$ the degree of condensation is lower than in most oxidic zeolites $(\mathrm{Al} / \mathrm{Si}: \mathrm{O}=1: 2)$. As a consequence terminal $\mathrm{N}^{[1]}$ occur besides simply bridging $\mathrm{N}^{[2]}$. A measure for the microporosity of zeolite analogous structures is the framework density (FD), which indicates the number of tetrahedral centres $(T)$ in a volume of $1000 \AA^{3}$. With $F D=18.5 \quad \mathrm{~T} /\left(1000 \AA^{3}\right)$ $\mathrm{Ba}_{2} \mathrm{Nd}_{7} \mathrm{Si}_{11} \mathrm{~N}_{23}$ is similar to typical zeolites ( $\mathrm{FD}$ values for some zeolites: $17.5 \quad\left(\mathrm{AlPO}_{4}-5\right), \quad 17.9 \quad$ (ZSM-5), 19.3 (Nonasil)). ${ }^{14}$

With highly cross-linked $\mathrm{N}^{[3]}$ and $\mathrm{N}^{[4]}$ as well as edgesharing of $\mathrm{SiN}_{4}$ tetrahedra the nitridosilicates represent a significant structural extension of conventional oxosilicates. Up to now we have focused our work on pure nitridosilicates. The purpose of this paper is to outline the capability of our synthetic procedure and to discuss its limits. Furthermore we present an extension of this approach to oxonitridosilicates and also to oxonitridoaluminosilicates (sialons). All sialons known so far contain corner-sharing $(\mathrm{Si}, \mathrm{Al})(\mathrm{O}, \mathrm{N})_{4}$ tetrahedra and they represent a link between oxidic silicates and the nitridosilicates with partial substitution of the tetrahedral centres by aluminium. ${ }^{15}$ Owing to their outstanding mechanical properties these sialons have gained remarkable significance for the development of high-performance materials. ${ }^{16}$

\section{Experimental}

\subsection{Radiofrequency furnace}

For the synthesis of nitridosilicates a specially developed computer processed radiofrequency (rf) furnace is used for the inductive heating of the crucibles. The crucible containing the reaction mixture is positioned on a tungsten stand inside a water cooled quartz reactor (Fig. 5). The reactor is surrounded by a water cooled induction coil wherein the crucible is centred. The induction coil is connected to a radiofrequency 


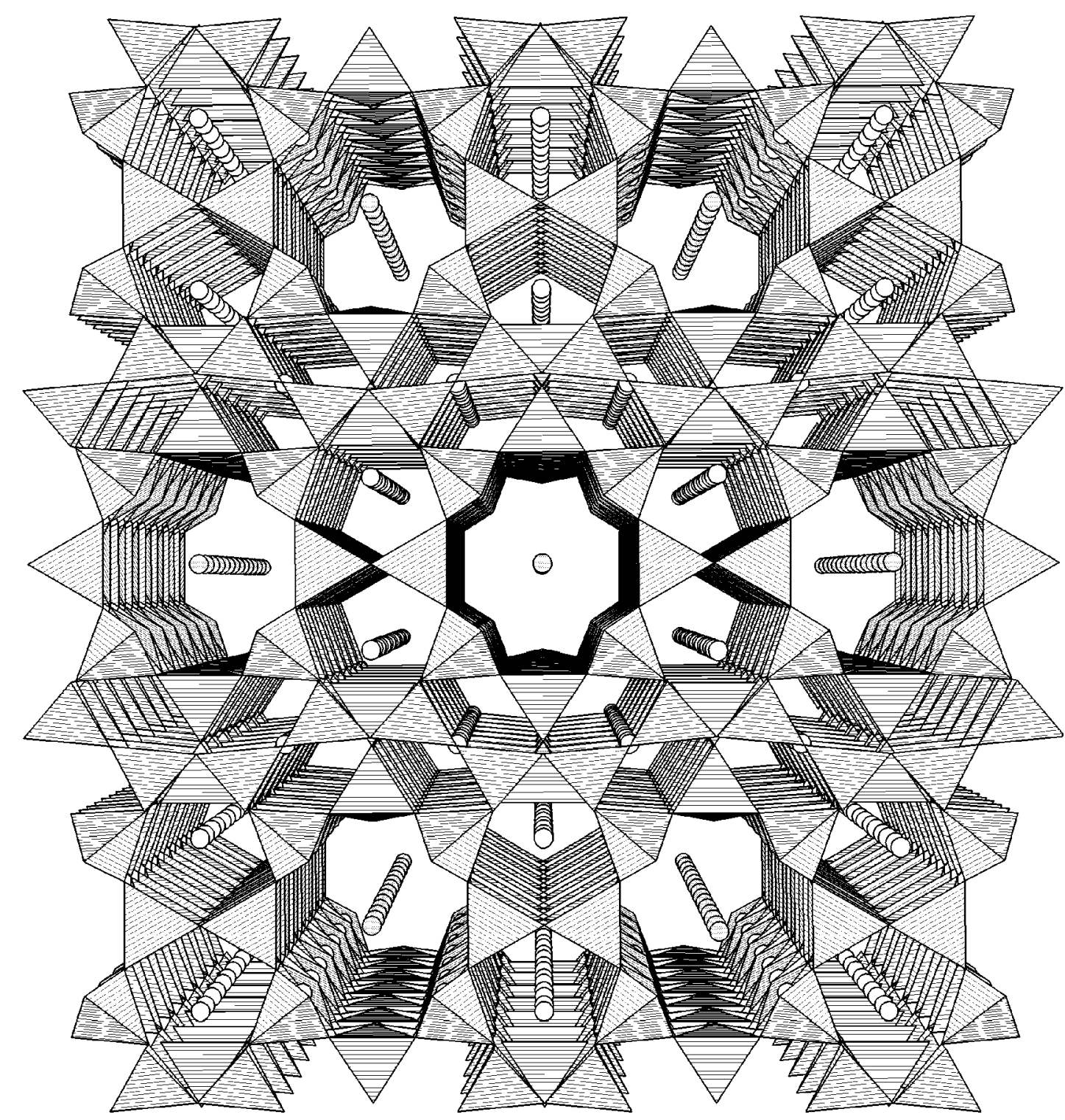

Fig. 4 Crystal structure of $\mathrm{Ba}_{2} \mathrm{Nd}_{7} \mathrm{Si}_{11} \mathrm{~N}_{23}$, which has a zeolite analogous $\mathrm{Si}-\mathrm{N}$ framework with wide channels.

generator (type: IG 30-400, Hüttinger, Freiburg, Germany) via the outer oscillating circuit. The power input of the generator aggregates a voltage of $380 \mathrm{~V}$ with a maximum current strength of $3 \times 120 \mathrm{~A}$, a power output of $0-36 \mathrm{~kW}$, and an effective maximum voltage of $7000 \mathrm{~V}$. The optimum working frequency depends on the crucible material and the gas atmosphere in the quartz reactor. For the selection of the crucible materials (e.g. tungsten, tantalum, graphite) specific properties like the chemical inertness and the electronic conductivity at high temperatures are considered. For tungsten crucibles in an argon atmosphere a working frequency of $600 \mathrm{kHz}$ is used. The energy transfer from the coil to the crucible is relatively poor (coupling constant: 0.28 ). This is due to the spatial separation in our experimental setup (diameter of the tungsten crucible: $24 \mathrm{~mm}$, induction coil: $72 \mathrm{~mm}$ ). Optimised tuning of the resonant cycle yields a maximum temperature of $2350{ }^{\circ} \mathrm{C}$ with tungsten crucibles and above $3000^{\circ} \mathrm{C}$ with graphite crucibles. For the thermal control of the crucible an external pyrometer is used. For reactions during which metals evaporate and condense on the inner surface of the quartz reactor power controlled temperature programs based on calibration curves obtained with empty crucibles are used. The quartz reactor is connected to a vacuum line and an inert gas supply $\left(\mathrm{Ar}, \mathrm{N}_{2}\right)$. With this experimental setup fast heating rates $\left(500{ }^{\circ} \mathrm{C} \mathrm{min}{ }^{-1}\right)$ but also quenching of the reaction products is possible.

\subsection{Synthesis of nitridosilicates and oxonitridosilicates}

The novel synthetic approach, abandoning the use of the binary nitrides and treating the pure metals with silicon diimide $\left[\mathrm{Si}(\mathrm{NH})_{2}\right]$ instead, proved to be successful for the synthesis of several nitridosilicates [eqn. (1) and (2)].

$$
2 \mathrm{M}+5 \mathrm{Si}(\mathrm{NH})_{2} \underset{\text { rf furnace }}{\stackrel{1500-1650^{\circ} \mathrm{C}}{\longrightarrow}} \mathrm{M}_{2} \mathrm{Si}_{5} \mathrm{~N}_{8}+\mathrm{N}_{2}+5 \mathrm{H}_{2}
$$

$(\mathrm{M}=\mathrm{Ca}, \mathrm{Sr}, \mathrm{Ba}, \mathrm{Eu})$

$$
3 \mathrm{M}^{\prime}+6 \mathrm{Si}(\mathrm{NH})_{2} \underset{\text { rf furnace }}{\stackrel{1650^{\circ} \mathrm{C}}{\longrightarrow}} \mathrm{M}_{3}^{\prime} \mathrm{Si}_{6} \mathrm{~N}_{11}+\frac{1}{2} \mathrm{~N}_{2}+6 \mathrm{H}_{2}
$$

$$
\left(\mathrm{M}^{\prime}=\mathrm{Ce}, \mathrm{Pr}\right)
$$

Silicon diimide $\mathrm{Si}(\mathrm{NH})_{2}$ is an amorphous and relatively undefined but reactive compound which converts to amorphous $\mathrm{Si}_{3} \mathrm{~N}_{4}$ at temperatures above $900^{\circ} \mathrm{C}$. It is an important precursor for the technical production of $\mathrm{Si}_{3} \mathrm{~N}_{4}$ ceramics. ${ }^{17}$

For the synthesis of silicon diimide $\mathrm{CH}_{2} \mathrm{Cl}_{2}$ ( $50 \mathrm{ml}$, Merck, p.a.) was saturated with dried $\mathrm{NH}_{3}(99.9 \%$, BASF, dried by condensation on sodium and potassium) at $-78^{\circ} \mathrm{C}$ under a purified argon atmosphere. A precooled solution of $\mathrm{SiCl}_{4}$ (20 ml, $0.17 \mathrm{~mol}$; Merck) in $\mathrm{CH}_{2} \mathrm{Cl}_{2}(30 \mathrm{ml})$ was slowly added with stirring [eqn. (3)]. The suspension was then warmed to room temperature under a $\mathrm{NH}_{3}$ atmosphere. The finely pow- 

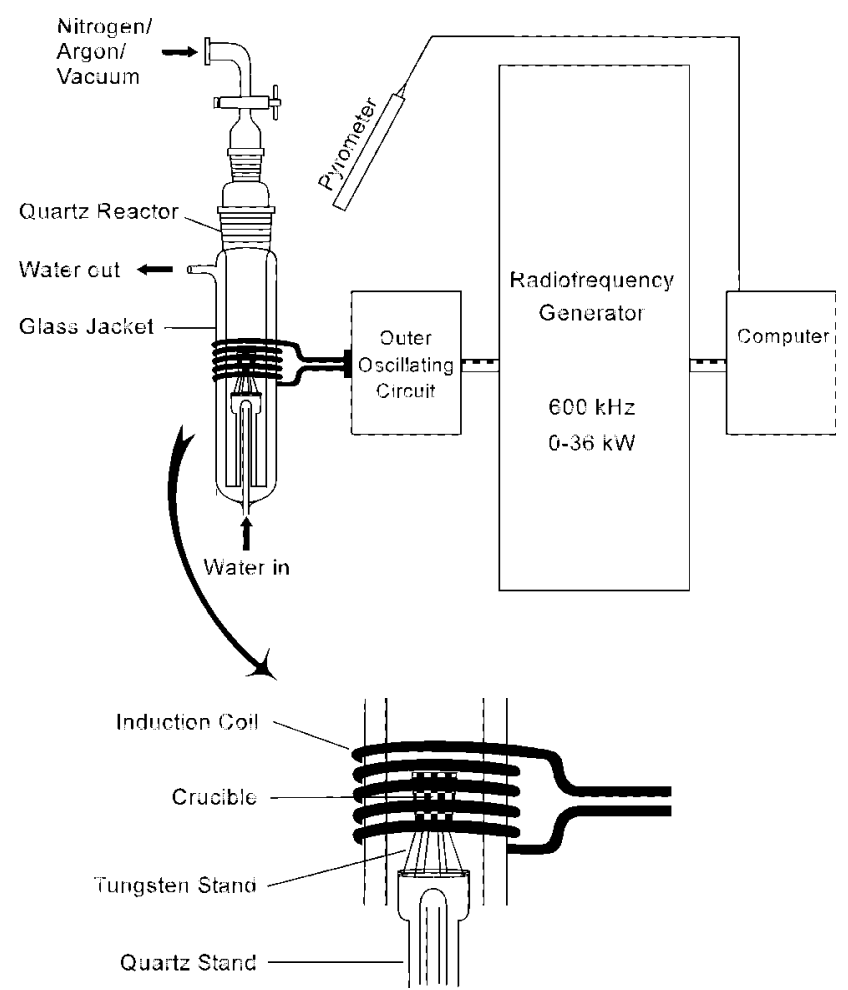

Fig. 5 Radiofrequency furnace for the synthesis of nitridosilicates and sialons.

dered residue was heated to $300{ }^{\circ} \mathrm{C}$ and finally to $600{ }^{\circ} \mathrm{C} .{ }^{17}$

$$
\mathrm{SiCl}_{4}+6 \mathrm{NH}_{3} \frac{\text { 1. } \mathrm{CH}_{2} \mathrm{Cl}_{2}}{\text { 2. } 600{ }^{\circ} \mathrm{C}} \mathrm{Si}(\mathrm{NH})_{2}+4 \mathrm{NH}_{4} \mathrm{Cl}
$$

The reaction between a metal and $\mathrm{Si}(\mathrm{NH})_{2}$ [eqn. (1) and (2)] may be interpreted as a dissolution of an electropositive metal in the nitrido analogous, polymeric acid $\mathrm{Si}(\mathrm{NH})_{2}$, accompanied by the evolution of hydrogen. Basically several metals with melting points below $1600^{\circ} \mathrm{C}$ can be used for this procedure. Similarly to the formation of $\mathrm{Si}_{3} \mathrm{~N}_{4}$ whiskers a vapour-solid (VS), ${ }^{18}$ a vapour-liquid-solid (VLS), ${ }^{19}$ or a liquid-solid (LS) mechanism is assumed for the synthesis of nitridosilicates. Preparative amounts of nitridosilicates as coarsely crystalline, single phase products are accessible by this procedure in short reaction times with metals melting at approximately $1000^{\circ} \mathrm{C}$. Depending on the molar ratio of metal and silicon diimide in the starting mixture highly cross-linked or lower condensed nitridosilicates are produced.

Recently we extended our synthetic attempts to nitridoaluminosilicates and also to compounds in the system $\mathrm{Si}-\mathrm{Al}-\mathrm{O}-\mathrm{N}$. These oxonitridoaluminosilicates (sialons) are built up of corner-sharing $(\mathrm{Si}, \mathrm{Al})(\mathrm{O}, \mathrm{N})_{4}$ tetrahedra and they derive from the nitridosilicates by formal substitution of $\mathrm{Si}$ by $\mathrm{Al}$ and $\mathrm{N}$ by $\mathrm{O}$. However owing to kinetic reasons such substitutions seem to be difficult starting from pure nitridosilicates or oxosilicates. Owing to its specific thermal behaviour $\mathrm{SrCO}_{3}$ is a useful starting material for the synthesis of oxonitridosilicates. For the respective aluminosilicates we additionally used AlN.

\subsection{Synthesis and analysis of $\operatorname{SrSiAl}_{2} \mathrm{O}_{3} \mathrm{~N}_{2}$ and $\operatorname{SrErSiAl}_{3} \mathrm{O}_{3} \mathrm{~N}_{4}$}

Both sialons were obtained by high temperature reaction of $\mathrm{SrCO}_{3}$ (Merck, p.a.), $\mathrm{Si}(\mathrm{NH})_{2}$ (see above), and AlN.

Single phase and crystalline aluminium nitride was obtained by the reaction of $\mathrm{Al}$ (Fluka, 99\%) in a continuous stream of nitrogen (Linde, 5.0). Five reaction cycles of $2 \mathrm{~h}$ each at $900{ }^{\circ} \mathrm{C}$ with subsequent grinding of the solid product were performed.

Additionally metallic erbium powder (ABCR, 99.9\%) was added to the reaction mixture for the synthesis of $\mathrm{SrErSiAl}_{3} \mathrm{O}_{3} \mathrm{~N}_{4}$. For the synthesis of $\mathrm{SrSiAl}_{2} \mathrm{O}_{3} \mathrm{~N}_{2}$ [values for $\mathrm{SrErSiAl}_{3} \mathrm{O}_{3} \mathrm{~N}_{4}$ in square brackets] $99.1 \mathrm{mg} \cong 1.70 \mathrm{mmol}$ silicon diimide [86.3 mg, $1.49 \mathrm{mmol}], \quad 103.3 \mathrm{mg} \cong 2.52 \mathrm{mmol}$ aluminium nitride [89.6 mg, $2.19 \mathrm{mmol}$ ], and $118.6 \mathrm{mg}$ $\cong 0.80 \mathrm{mmol}$ strontium carbonate $[95.6 \mathrm{mg}, 0.64 \mathrm{mmol}$ and additionally $124.3 \mathrm{mg} \cong 0.74 \mathrm{mmol}$ erbium] were thoroughly mixed under an argon atmosphere in a glove box. In a tungsten crucible the mixture was then transferred into the quartz reactor of the $\mathrm{rf}$ furnace. Under pure nitrogen atmosphere the temperature was increased to $1200{ }^{\circ} \mathrm{C}$ with a heating rate of

Table 1 Crystallographic data for $\mathrm{SrSiAl}_{2} \mathrm{O}_{3} \mathrm{~N}_{2}$ (esds in parentheses)

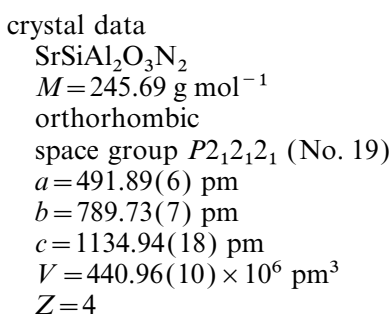

data collection

Siemens P4 diffractometer $\omega$-scans

absorption correction: $\psi$ scans

$T_{\min }=0.2231 ; T_{\max }=0.2759$

$R_{\text {int }}=0.0400$

$\theta_{\max }=30$

$$
\begin{aligned}
& \text { refinement } \\
& \text { refinement on } F^{2} \\
& R_{1}=0.0439 \\
& w R_{2}=0.0939 \\
& \mathrm{GOF}=1.080
\end{aligned}
$$

82 parameters

data collection and cell refinement: Siemens xscans
$D_{\mathrm{c}}=3.701 \mathrm{~g} \mathrm{~cm}^{-3}$

Mo-K $\alpha$ radiation

$\lambda=71.073 \mathrm{pm}$

cell parameters from 24 reflections

$\theta=7-15^{\circ}$

$\mu=12.795 \mathrm{~mm}^{-1}$

$T=296(2) \mathrm{K}$

prism

$0.08 \times 0.15 \times 0.12 \mathrm{~mm}$

colourless

measured octants: $h k l$ and $\bar{h} \bar{k} \bar{l}$ with

$h=-6 \rightarrow 6$

$k=-11 \rightarrow 11$

$l=-15 \rightarrow 15$

1544 measured reflections

1280 independent reflections

1280 observed reflections $\left[F_{\mathrm{o}}^{2} \geqslant 0 \sigma\left(F_{\mathrm{o}}^{2}\right)\right]$

standard check frequency: 3 in 100

program used to refine structure: SHELXL-93 ${ }^{20}$

$w^{-1}=\sigma^{2} F_{\mathrm{o}}{ }^{2}+(x P)^{2}+y P ; P=\left(F_{\mathrm{o}}{ }^{2}+2 F_{\mathrm{c}}{ }^{2}\right) / 3$

weighting $(x / y) 0.0509 / 0$

Flack parameter: $0.06(2)$

min. residual electron density: -0.944 e $\AA^{-3}$

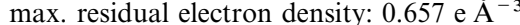


$10{ }^{\circ} \mathrm{C} \min ^{-1}\left[1200{ }^{\circ} \mathrm{C}, 20^{\circ} \mathrm{C} \mathrm{min}^{-1}\right]$ and then to $1550{ }^{\circ} \mathrm{C}$ at $3{ }^{\circ} \mathrm{C} \min ^{-1}\left[1670{ }^{\circ} \mathrm{C}, 8^{\circ} \mathrm{C} \mathrm{min}^{-1}\right]$. This temperature was maintained for $30 \mathrm{~min}$ and then the reaction mixture was cooled to $800^{\circ} \mathrm{C}$ with a cooling rate of $0.2^{\circ} \mathrm{C} \mathrm{min}^{-1}\left[900^{\circ} \mathrm{C}\right.$, $\left.0.2^{\circ} \mathrm{C} \mathrm{min}{ }^{-1}\right]$. Finally room temperature was reached within $30 \mathrm{~min}$ [10 min]. $\mathrm{SrSiAl}_{2} \mathrm{O}_{3} \mathrm{~N}_{2}$ was obtained as a colourless crystalline solid $\left[\mathrm{SrErSiAl}_{3} \mathrm{O}_{3} \mathrm{~N}_{4}\right.$ is transparent and has a pink colour].

According to X-ray powder diffraction studies $\mathrm{SrSiAl}_{2} \mathrm{O}_{3} \mathrm{~N}_{2}$ and $\mathrm{SrErSiAl}_{3} \mathrm{O}_{3} \mathrm{~N}_{4}$ each were obtained with a yield of approximately $20 \%$. Byproducts of the reactions were $\mathrm{Sr}_{2} \mathrm{SiO}_{4}$ and $\mathrm{Sr}_{3} \mathrm{Al}_{2} \mathrm{O}_{6}$, which have been identified by X-ray powder diffrac- tion analysis. In the case of $\mathrm{SrErSiAl}_{3} \mathrm{O}_{3} \mathrm{~N}_{4}$ also glassy $\mathrm{Sr}-\mathrm{Er}$-sialons were obtained as detected by EDX analysis.

The absence of hydrogen $(\mathrm{N}-\mathrm{H})$ in the products was established by IR spectroscopy. The nitrogen content of $\mathrm{SrSiAl}_{2} \mathrm{O}_{3} \mathrm{~N}_{2}$ (theoretical value: $11.4 \%$ ) as determined by photometry was $11.1 \mathrm{wt} . \%$. EDX analytical investigations resulted in the following values (wt.\%) (theoretical values in parentheses). $\mathrm{SrSiAl}_{2} \mathrm{O}_{3} \mathrm{~N}_{2}$ : $\mathrm{Sr} 32.8$ (35.67), Si 13.4 (11.43), Al 21.8 (21.96), O 19.7 (19.54), N 9.3 (11.40); $\mathrm{SrErSiAl}_{3} \mathrm{O}_{3} \mathrm{~N}_{4}$ : $\mathrm{Er}$ 36.8 (35.74), Sr 19.3 (18.72), Si 6.6 (6.60), Al 18.8 (17.30), O 10.9 (10.26), N 9.9 (11.98).

For X-ray investigations an irregularly shaped (needle

Table 2 Atomic coordinates and thermal parameters $\left(\AA^{2}\right)$ for $\operatorname{SrSiAl}_{2} \mathrm{O}_{3} \mathrm{~N}_{2}$ with esds in parentheses

\begin{tabular}{|c|c|c|c|c|c|c|c|c|c|c|c|}
\hline Atom & Wyckoff-position & $x / a$ & $y / b$ & $z / c$ & $U_{11}$ & $U_{22}$ & $U_{33}$ & $U_{23}$ & $U_{13}$ & $U_{12}$ & $U_{\text {iso }}$ \\
\hline $\mathrm{Sr} 1$ & $4 a$ & $0.9912(2)$ & $0.95868(8)$ & $0.66580(5)$ & $0.0189(3)$ & $0.0156(3)$ & $0.0152(3)$ & $-0.0028(2)$ & $0.0021(5)$ & $-0.0010(5)$ & $0.0166(2)$ \\
\hline Al1 & $4 a$ & $0.9961(6)$ & $0.8332(2)$ & $0.3436(1)$ & $0.0056(7)$ & $0.0017(6)$ & $0.0061(7)$ & $-0.0001(6)$ & $0.002(1)$ & $-0.0005(9)$ & $0.0045(3)$ \\
\hline $\mathrm{A} 12$ & $4 a$ & $0.9866(5)$ & $0.5311(2)$ & $0.5429(1)$ & $0.0038(7)$ & $0.0031(6)$ & $0.0067(7)$ & $0.0001(6)$ & $0.0001(9)$ & $-0.001(1)$ & $0.0045(3)$ \\
\hline Sil & $4 a$ & $0.0138(5)$ & $0.2013(2)$ & $0.4195(1)$ & $0.0077(8)$ & $0.0078(6)$ & $0.0102(7)$ & $-0.0003(6)$ & $0.001(1)$ & $0.001(1)$ & $0.0086(3)$ \\
\hline $\mathrm{O} 1$ & $4 a$ & $0.9586(12)$ & $0.6542(6)$ & $0.4235(5)$ & $0.020(3)$ & $0.020(2)$ & $0.022(3)$ & $0.007(2)$ & $-0.007(3)$ & $-0.008(2)$ & $0.021(1)$ \\
\hline $\mathrm{O} 2$ & $4 a$ & $0.8329(11)$ & $0.6230(7)$ & $0.6616(5)$ & $0.016(3)$ & $0.016(3)$ & $0.021(3)$ & $-0.002(2)$ & $0.001(2)$ & $0.004(2)$ & $0.018(1)$ \\
\hline $\mathrm{O} 3$ & $4 a$ & $0.1288(11)$ & $0.2870(7)$ & $0.2903(5)$ & $0.020(3)$ & $0.027(3)$ & $0.017(3)$ & $0.005(3)$ & $0.004(2)$ & $-0.005(3)$ & $0.021(1)$ \\
\hline N1 & $4 a$ & $0.8217(12)$ & $0.0084(7)$ & $0.4101(5)$ & $0.008(3)$ & $0.011(3)$ & $0.018(3)$ & $-0.006(2)$ & $0.001(2)$ & $-0.001(2)$ & $0.012(1)$ \\
\hline N2 & $4 a$ & $0.8126(12)$ & $0.3485(7)$ & $0.4977(5)$ & $0.007(3)$ & $0.010(3)$ & $0.015(3)$ & $0.002(2)$ & $0.003(2)$ & $-0.001(2)$ & $0.011(1)$ \\
\hline
\end{tabular}

Table 3 Bond distances $(\mathrm{pm})$ and angles $\left(^{\circ}\right)$ in $\mathrm{SrSiAl}_{2} \mathrm{O}_{3} \mathrm{~N}_{2}$ with esds in parentheses

\begin{tabular}{|c|c|c|c|c|c|}
\hline $\mathrm{Sr} 1-\mathrm{O} 2$ & $250.4(6)$ & Al1-O3 & $167.9(6)$ & Sil-O3 & $171.2(6)$ \\
\hline $\mathrm{Sr} 1-\mathrm{O} 1$ & $266.6(6)$ & $\mathrm{Al1}-\mathrm{O} 1$ & $168.9(5)$ & Si1-N2 & $176.7(6)$ \\
\hline $\mathrm{Sr} 1-\mathrm{O} 3$ & $273.1(6)$ & $\mathrm{A} 11-\mathrm{O} 2$ & $169.4(6)$ & $\mathrm{Si} 1-\mathrm{N} 2$ & $178.8(6)$ \\
\hline $\mathrm{Sr} 1-\mathrm{O} 2$ & $276.4(5)$ & Al1-N1 & $179.4(6)$ & Si1-N1 & $179.6(6)$ \\
\hline $\mathrm{Sr} 1-\mathrm{N} 2$ & $287.4(6)$ & & & & \\
\hline $\mathrm{Sr} 1-\mathrm{O} 1$ & $294.7(6)$ & $\mathrm{A} 12-\mathrm{O} 1$ & $167.4(5)$ & & \\
\hline $\mathrm{Sr} 1-\mathrm{O} 3$ & $304.2(6)$ & $\mathrm{A} 12-\mathrm{O} 2$ & $170.6(6)$ & & \\
\hline Sr1-N1 & $304.5(6)$ & $\mathrm{A} 12-\mathrm{N} 2$ & $175.4(6)$ & & \\
\hline Sr1-N1 & $318.2(6)$ & $\mathrm{A} 12-\mathrm{N} 1$ & $176.1(6)$ & & \\
\hline $\mathrm{A} 11-\mathrm{O} 1-\mathrm{A} 12$ & $115.7(4)$ & $\mathrm{A} 11-\mathrm{N} 1-\mathrm{A} 12$ & $116.0(3)$ & $\mathrm{Si} 1-\mathrm{N} 2-\mathrm{A} 12$ & $114.5(3)$ \\
\hline $\mathrm{A} 11-\mathrm{O} 2-\mathrm{A} 12$ & $119.6(3)$ & $\mathrm{Si} 1-\mathrm{N} 1-\mathrm{A} 12$ & $128.7(4)$ & $\mathrm{Si} 1-\mathrm{N} 2-\mathrm{A} 12$ & $115.4(3)$ \\
\hline Si1-O3-Al1 & $137.8(4)$ & Si1-N1-Al1 & $115.3(3)$ & Si1-N2-Si1 & $125.4(3)$ \\
\hline
\end{tabular}

Table 4 Crystallographic data for $\mathrm{SrErSiAl}_{3} \mathrm{O}_{3} \mathrm{~N}_{4}$ (esds in parentheses)

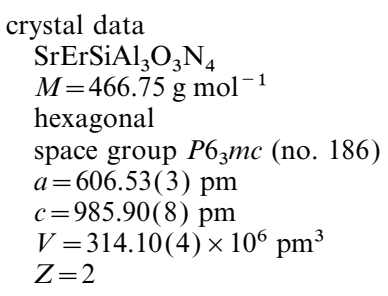
data collection
Siemens P4 diffractometer
$\omega$-scans
absorption correction: $\psi$-scans
$T_{\min }=0.5662 ; T_{\max }=0.8358$
$R_{\text {int }}=0.0359$
$\theta_{\max }=30^{\circ}$
refinement
refinement on $F^{2}$
$R_{1}=0.0151$
$w R_{2}=0.0338$
$\mathrm{GOF}=1.107$

33 parameters

data collection and cell refinement: Siemens xscans
$D_{\mathrm{c}}=5.245 \mathrm{~g} \mathrm{~cm}^{-3}$

Mo-K $\alpha$ radiation

$\lambda=71.073 \mathrm{pm}$

cell parameters from 64 reflections

$\theta=6-19^{\circ}$

$\mu=22.530 \mathrm{~mm}^{-1}$

$T=296(2) \mathrm{K}$

prism

$0.06 \times 0.08 \times 0.12 \mathrm{~mm}$

light pink

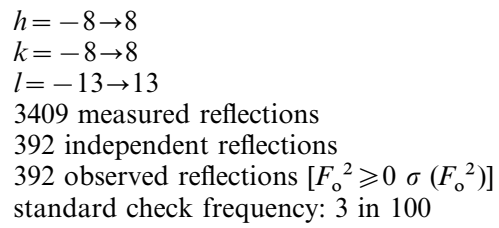

program used to refine structure: SHELXL-93 ${ }^{20}$

$w^{-1}=\sigma^{2} F_{\mathrm{o}}{ }^{2}+(x P)^{2}+y P ; P=\left(F_{\mathrm{o}}{ }^{2}+2 F_{\mathrm{c}}{ }^{2}\right) / 3$

weighting $(x / y) 0.0188 / 0.5884$

extinction coefficient: $0.021(1)$

Flack parameter: $0.34(2)$

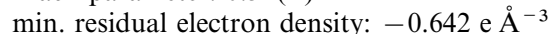

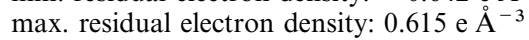


Table 5 Atomic coordinates and thermal parameters $\left(\AA^{2}\right)$ for $\operatorname{SrErSiAl}{ }_{3} \mathrm{O}_{3} \mathrm{~N}_{4}$ with esds in parentheses

\begin{tabular}{|c|c|c|c|c|c|c|c|c|c|c|c|}
\hline Atom & Wyckoff-position & $x / a$ & $y / b$ & $z / c$ & $U_{11}$ & $U_{22}$ & $U_{33}$ & $U_{23}$ & $U_{13}$ & $U_{12}$ & $U_{\text {iso }}$ \\
\hline Er1 & $2 b$ & $1 / 3$ & $2 / 3$ & $0.62727(0)$ & $0.0085(1)$ & $U_{11}$ & $0.0033(2)$ & 0 & 0 & $1 / 2 U_{11}$ & $0.0067(1)$ \\
\hline Sr1 & $2 b$ & $1 / 3$ & $2 / 3$ & $0.25830(9)$ & $0.0192(3)$ & $U_{11}$ & $0.0146(5)$ & 0 & 0 & $1 / 2 U_{11}$ & $0.0177(2)$ \\
\hline Al1 & $6 c$ & $0.6607(3)$ & $0.8304(1)$ & $0.9406(2)$ & $0.0042(6)$ & $0.0041(4)$ & $0.0018(5)$ & $1 / 2 U_{13}$ & $-0.0017(8)$ & $1 / 2 U_{11}$ & $0.0033(2)$ \\
\hline Sil & $2 \mathrm{a}$ & 0 & 0 & $0.7002(3)$ & $0.0076(7)$ & $U_{11}$ & $0.005(1)$ & 0 & 0 & $1 / 2 U_{11}$ & $0.0066(5)$ \\
\hline $\mathrm{O} 1$ & $6 c$ & $0.4907(6)$ & $0.9813(9)$ & $0.9912(5)$ & $0.018(2)$ & $0.021(2)$ & $0.031(2)$ & $-0.013(2)$ & $1 / 2 U_{23}$ & $1 / 2 U_{22}$ & $0.023(1)$ \\
\hline N1 & $6 c$ & $0.6945(9)$ & $0.8472(5)$ & $0.7625(4)$ & $0.003(2)$ & $0.036(2)$ & $0.002(2)$ & $1 / 2 U_{13}$ & $0.001(2)$ & $1 / 2 U_{11}$ & $0.017(1)$ \\
\hline N2 & $2 \mathrm{a}$ & 0 & 0 & $0.0124(9)$ & $0.013(3)$ & $U_{11}$ & $0.009(4)$ & 0 & 0 & $1 / 2 U_{11}$ & $0.012(3)$ \\
\hline
\end{tabular}

Table 6 Bond distances (pm) and angles $\left({ }^{\circ}\right)$ in $\operatorname{SrErSiAl}_{3} \mathrm{O}_{3} \mathrm{~N}_{4}$ with esds in parentheses

\begin{tabular}{llllll}
\hline Er1-O1 & $228.4(6)$ & $(3 \times)$ & Al1-O1 & $175.9(3)$ & $(2 \times)$ \\
Er1-N1 & $231.9(5)$ & $(3 \times)$ & Al1-N1 & $176.5(4)$ & \\
Sr1-O1 & $294.8(6)$ & $(3 \times)$ & Al1-N2 & $191.8(4)$ & \\
Sr1-N1 & $303.65(3)$ & $(6 \times)$ & Si1-N1 & $171.8(5)$ & $(3 \times)$ \\
Sr1-O1 & $310.9(6)$ & $(3 \times)$ & Si1-N2 & $185.1(9)$ & \\
& & & & & \\
A11-O1-A11 & $115.6(3)$ & & Si1-N2-Al1 & $111.7(2)$ & $(3 \times)$ \\
Si1-N1-A11 & $116.7(3)$ & & Al1-N2-A11 & $107.2(3)$ & $(3 \times)$ \\
\hline
\end{tabular}

shaped) single crystal of $\mathrm{SrSiAl}_{2} \mathrm{O}_{3} \mathrm{~N}_{2}\left[\mathrm{SrErSiAl}_{3} \mathrm{O}_{3} \mathrm{~N}_{4}\right]$ was separated from the byproducts. Details of the structure determination are summarised in Table 1 [4], atomic coordinates and bond lengths are listed in Tables 2 and 3 [5 and 6].

Full crystallographic details, excluding structure factors, have been deposited at the Cambridge Crystallographic Data Center (CCDC). See Information for Authors, J. Mater. Chem., 1999, Issue 1. Any request to the CCDC for this material should quote the full literature citation and the reference number 1145/105.

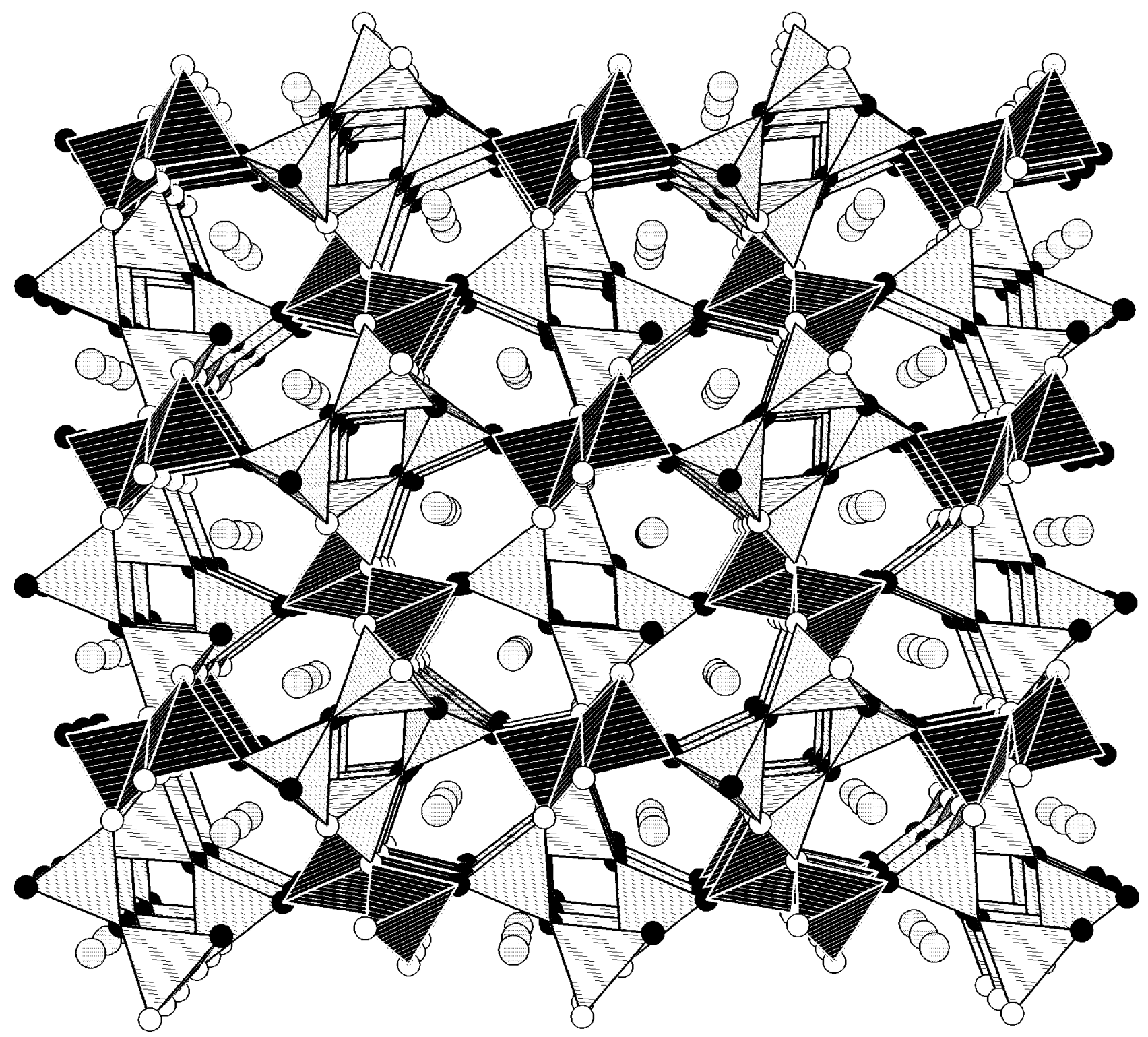

Fig. 6 Crystal structure of $\mathrm{SrSiAl}_{2} \mathrm{O}_{3} \mathrm{~N}_{2}$. View along [100]. The $\mathrm{AlO}_{3} \mathrm{~N}$ and the $\mathrm{AlO}_{2} \mathrm{~N}_{2}$ tetrahedra are shown as grey, the $\mathrm{SiON}$ tetrahedra as black polyhedra. Black spheres represent $\mathrm{O}$, white spheres $\mathrm{N}$, and grey spheres $\mathrm{Sr}$ atoms. 


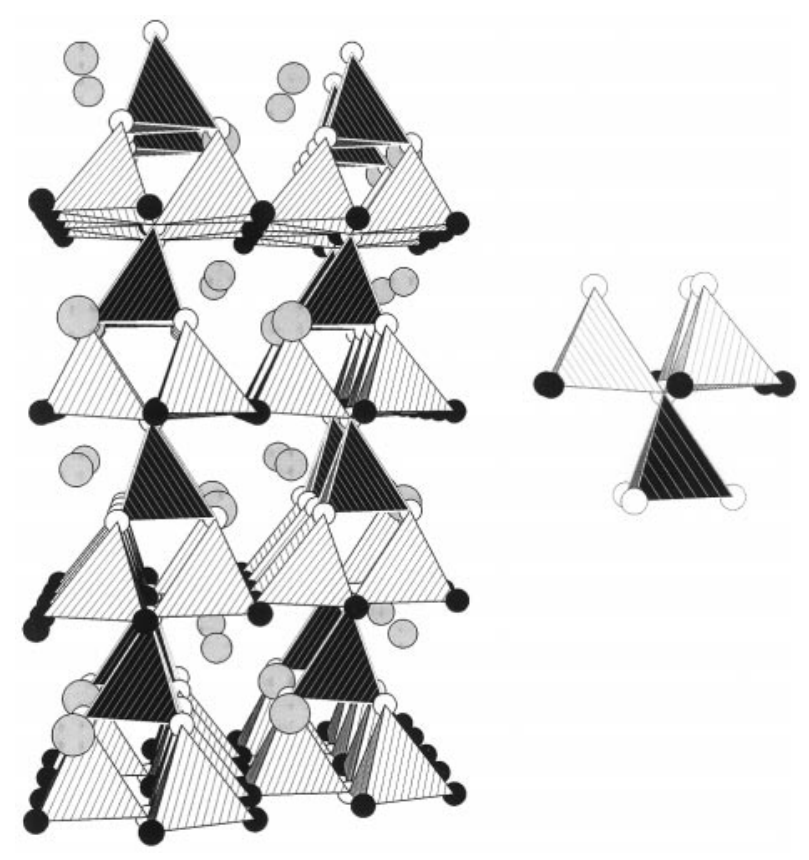

Fig. 7 Left side: crystal structure of $\mathrm{SrErSiAl}_{3} \mathrm{O}_{3} \mathrm{~N}_{4}$. The $\mathrm{SiN}_{4}$ tetrahedra are shown as black, the $\mathrm{AlO}_{2} \mathrm{~N}_{2}$ tetrahedra as grey polyhedra. Black spheres represent $\mathrm{O}$, white spheres $\mathrm{N}$, the large grey spheres $\mathrm{Sr}$, and smal grey spheres $\mathrm{Er}$ atoms. Right side: coordination of the $\mathrm{N}^{[4]}$ atoms.

\subsection{Discussion}

During the last 25 years several sialons have been synthesised but only a very few of them have been fully characterised by single crystal X-ray methods. Only in one case was the differentiation of $\mathrm{Al} / \mathrm{Si}$ and $\mathrm{O} / \mathrm{N}$, respectively, unambiguously possible. ${ }^{21}$ Structurally the most sialons derive from nitrides like $\alpha$ - and $\beta-\mathrm{Si}_{3} \mathrm{~N}_{4}, \mathrm{AlN}, \mathrm{Si}_{2} \mathrm{~N}_{2} \mathrm{O}_{2}$, or oxides like spinel, melilite or apatite. ${ }^{16} \mathrm{SrSiAl}_{2} \mathrm{O}_{3} \mathrm{~N}_{2}$ and $\mathrm{SrErSiAl}_{3} \mathrm{O}_{3} \mathrm{~N}_{4}$ are the first examples which are isotypic with nitridosilicates.

$\mathrm{SrSiAl}_{2} \mathrm{O}_{3} \mathrm{~N}_{2}$ crystallises in a variant of the $\mathrm{LnSi}_{3} \mathrm{~N}_{5}$ structure type $(\mathrm{Ln}=\mathrm{La}, \mathrm{Ce}, \mathrm{Pr}, \mathrm{Nd}) .{ }^{22-24}$ Corner-sharing $\mathrm{SiON}_{3}$, $\mathrm{AlO}_{3} \mathrm{~N}$ and $\mathrm{AlO}_{2} \mathrm{~N}_{2}$ tetrahedra form a highly condensed network (Fig. 6). The $\mathrm{Al} / \mathrm{Si}$ as well as the $\mathrm{O} / \mathrm{N}$, respectively, are unambiguously distinguishable because they are each located at different crystallographic sites. In the nitridosilicates $\mathrm{LnSi}_{3} \mathrm{~N}_{5}(\mathrm{Ln}=\mathrm{La}, \mathrm{Ce}, \mathrm{Pr}, \mathrm{Nd})$ these sites are only occupied by $\mathrm{Si}$ and $\mathrm{N}$, respectively. This differentiation also is supported by lattice energetic calculations using the MAPLE concept. ${ }^{25-27}$ Furthermore a significant differentiation of the bond lengths $(\mathrm{Al} / \mathrm{Si})-(\mathrm{N} / \mathrm{O})$ occurs according to $\mathrm{Al}-\mathrm{O}<\mathrm{Al}-\mathrm{N}$ and $\mathrm{Si}-\mathrm{O}<\mathrm{Si}-\mathrm{N}$ (Table 2). This corresponds with the respective bond valence parameters $\left(v_{\mathrm{Al}-\mathrm{O}}: 1.65, v_{\mathrm{Al}-\mathrm{N}}: 1.79, v_{\mathrm{Si}-\mathrm{O}}: 1.62\right.$, $\left.v_{\mathrm{Si}-\mathrm{N}}: 1.77 \mathrm{pm}\right){ }^{28}$ Analogously to oxosilicates the oxygen atoms in $\mathrm{SrSiAl}_{2} \mathrm{O}_{3} \mathrm{~N}_{2}$ are each bridging two tetrahedral centres $(\mathrm{Si}, \mathrm{Al})$ according to ${ }_{\infty}^{3}\left[\left(\mathrm{Si}_{1}{ }^{[4]} \mathrm{Al}_{2}{ }^{[4]} \mathrm{O}_{3}{ }^{[2]} \mathrm{N}_{2}{ }^{[3]}\right)^{2-}\right]$. The oxygen atoms $\mathrm{O} 1$ and $\mathrm{O} 2$ are only connected to $\mathrm{Al}$. $\mathrm{O} 3$ is bridging $\mathrm{Si}$ and $\mathrm{Al}$. N1 bridges two $\mathrm{Al}$ and one $\mathrm{Si}, \mathrm{N} 2$ links two $\mathrm{Si}$ and one $\mathrm{Al}$. The angular sum on these $\mathrm{N}^{[3]}$ atoms amounts to $360^{\circ}(\mathrm{N} 1)$ and $355^{\circ}(\mathrm{N} 2)$, respectively.

The $\mathrm{Sr}^{2+}$ ions are located in the channels of the $\left(\mathrm{SiAl}_{2} \mathrm{O}_{3} \mathrm{~N}_{2}\right)^{2-}$ network and they are coordinated by six $\mathrm{O}$ and three $\mathrm{N}$ atoms $\left[\mathrm{Sr}^{-} \mathrm{O}\right.$ 250.4(6)-304.2(6), $\mathrm{Sr}^{-} \mathrm{N}$ : 287.4(6)-318.2(6) pm]. The distances correspond to the sum of the ionic radii. Analogously with the $(\mathrm{Si} / \mathrm{Al})-(\mathrm{N} / \mathrm{O})$ bond lengths we found shorter distances $\mathrm{Sr}^{-} \mathrm{O}$ as compared with $\mathrm{Sr}-\mathrm{N} .^{28}$

The second new sialon $\mathrm{SrErSiAl}_{3} \mathrm{O}_{3} \mathrm{~N}_{4}$ also adopts a nitridosilicate structure type and is isotypic with $\mathrm{MYbSi}_{4} \mathrm{~N}_{7}(\mathrm{M}=\mathrm{Sr}$, $\mathrm{Ba}, \mathrm{Eu}){ }^{8-10} \mathrm{It}$ is the first sialon containing $\mathrm{N}^{[4]}$ atoms coval- ently bound to four tetrahedral centres $(\mathrm{Al} / \mathrm{Si})$. Formally these $\mathrm{N}^{[4]}$ have an ammonium character. The structure is built up by corner-sharing $\mathrm{SiN}_{4}$ and $\mathrm{AlO}_{2} \mathrm{~N}_{2}$ tetrahedra forming star shaped $\left[\mathrm{N}^{[4]}\left(\mathrm{SiN}_{3}{ }^{[2]}\right)\left(\mathrm{AlO}_{2}{ }^{[2]} \mathrm{N}^{[2]}\right)_{3}\right]$ units. These units are connected through the $\mathrm{O}^{[2]}$ and $\mathrm{N}^{[2]}$ atoms. (Fig. 7). The $\mathrm{Al}$ and $\mathrm{Si}$ atoms as well as the $\mathrm{O}$ and $\mathrm{N}$ atoms, respectively, are clearly distinguishable because they occupy different crystallographic sites. Although X-ray diffraction normally does not allow a precise differentiation of $\mathrm{Al} / \mathrm{Si}$ and $\mathrm{N} / \mathrm{O}$, respectively, also for $\mathrm{SrErSiAl}_{3} \mathrm{O}_{3} \mathrm{~N}_{4}$ the crystallographic ordering is confirmed by the results of lattice energetic calculations using the MAPLE concept. ${ }^{25-27}$

$\mathrm{The}^{2+}$ and $\mathrm{Er}^{3+}$ are located in channels along [100]. The $\mathrm{Sr}^{2+}$ are anticuboctahedrally coordinated by $\mathrm{N}^{[2]}$ and $\mathrm{O}^{[2]}$ [ $\mathrm{Sr}-\mathrm{O}$ 294.8(6)-310.9(6) pm, $\mathrm{Sr}-\mathrm{N}$ 303.65(3) pm], $\mathrm{Er}^{3+}$ is octahedrally coordinated [ $\mathrm{Er}-\mathrm{O} 228.4(6), \mathrm{Er}-\mathrm{N} 231.9(5) \mathrm{pm}]$. The distances correspond to the sum of the ionic radii. ${ }^{29}$ The bonds $\mathrm{Si}^{-} \mathrm{N}^{[4]}[185.1(9) \mathrm{pm}]$ and $\mathrm{Al}^{-} \mathrm{N}^{[4]}$ [191.8(4) pm] are significantly longer as compared to $\mathrm{Si}^{-} \mathrm{N}^{[2]}$ and $\mathrm{Al}-\mathrm{N}^{[2]}$. Presumably this is due to a repulsion between the positively polarised $\mathrm{N}^{[4]}$ and the cationic tetrahedral centres $\mathrm{Al}$ and $\mathrm{Si}$. Interestingly, the differentiation $\mathrm{Si}^{-} \mathrm{N}^{[4]}<\mathrm{Al}^{-} \mathrm{N}^{[4]}$ in $\mathrm{SrErSiAl}_{3} \mathrm{O}_{3} \mathrm{~N}_{4}$ occurs very similarly for the respective atoms in the aristo-type structure of $\mathrm{MYbSi}_{4} \mathrm{~N}_{7}(\mathrm{M}=\mathrm{Sr}, \mathrm{Ba}, \mathrm{Eu})$, where all tetrahedral centres of the network are only $\mathrm{Si}^{8-10}$ As expected in $\mathrm{SrErSiAl}_{3} \mathrm{O}_{3} \mathrm{~N}_{4}$ and $\mathrm{MYbSi}_{4} \mathrm{~N}_{7}(\mathrm{M}=\mathrm{Sr}, \mathrm{Ba}$, $\mathrm{Eu})$ the $\mathrm{N}^{[4]}$ atoms show no coordinative contribution towards the metal cations. The distances $\mathrm{Si}^{-} \mathrm{O}^{[2]}[171.8(5) \mathrm{pm}]$ and $\mathrm{Al}^{-} \mathrm{N}^{[2]}[176.5(4) \mathrm{pm}]$ are comparable with normal $\mathrm{Si}^{-} \mathrm{O}$ or $\mathrm{Al}-\mathrm{N}$ bonds.

\subsection{Conclusions}

The high temperature synthetic approach to nitridosilicates can easily be adopted for the preparation of novel highly condensed sialons. The two oxonitrides $\mathrm{SrSiAl}_{2} \mathrm{O}_{3} \mathrm{~N}_{2}$ and $\mathrm{SrErSiAl}_{3} \mathrm{O}_{3} \mathrm{~N}_{4}$ are structurally related to nitridosilicates and both compounds represent a link between nitridosilicates and oxosilicates.

$\mathrm{SrSiAl}_{2} \mathrm{O}_{3} \mathrm{~N}_{2}$ and $\mathrm{SrErSiAl}_{3} \mathrm{O}_{3} \mathrm{~N}_{4}$ are two of a very few sialons which have been fully characterised by single crystal $\mathrm{X}$-ray methods and they represent novel structure types for this class of materials. In both compounds a crystallographic differentiation $\mathrm{Al} / \mathrm{Si}$ and $\mathrm{O} / \mathrm{N}$ seems to be reasonable on the basis of lattice energetic calculations because the $\mathrm{Al}, \mathrm{Si}, \mathrm{O}$, and $\mathrm{N}$ atoms are located at different sites which in the isotypic nitridosilicates are only occupied by $\mathrm{Si}$ and $\mathrm{N}$, respectively.

Similarly to several sialons $\mathrm{SrSiAl}_{2} \mathrm{O}_{3} \mathrm{~N}_{2}$ and $\mathrm{SrErSiAl}_{3} \mathrm{O}_{3} \mathrm{~N}_{4}$ are very hard materials which even scratch agate. Both compounds have a thermal stability up to $1800^{\circ} \mathrm{C}$ and they are chemically resistant to hot acid and alkali.

This work has been supported by the Fonds der Chemischen Industrie and especially by the Deutsche Forschungsgemeinschaft (Schwerpunktprogramm 'Nitridobrücken' and Gottfried-Wilhelm-Leibniz Programm).

\section{References}

1 W. Schnick, Angew. Chem., Int. Ed. Engl., 1993, 32, 806.

2 H.-P. Baldus and M. Jansen, Angew. Chem., Int. Ed. Engl., 1997, 36, 328.

3 W. Schnick and H. Huppertz, Chem. Eur. J., 1997, 3, 679.

4 T. Schlieper and W. Schnick, Z. Anorg. Allg. Chem., 1995, 621, 1037.

5 T. Schlieper, W. Milius and W. Schnick, Z. Anorg. Allg. Chem., 1995, 621, 1380

6 T. Schlieper and W. Schnick, Z. Anorg. Allg. Chem., 1995, 621, 1535 .

7 T. Schlieper and W. Schnick, Z. Kristallogr., 1996, 211, 254.

8 H. Huppertz and W. Schnick, Angew. Chem., Int. Ed. Engl., 1996, 35, 1983. 
9 H. Huppertz and W. Schnick, Z. Anorg. Allg. Chem., 1997, 623, 212.

10 H. Huppertz and W. Schnick, Acta Crystallogr., Sect. C, 1997, 53, 1751 .

11 A. Weiss and A. Weiss, Z. Anorg. Allg. Chem., 1954, 276, 95.

12 H. Huppertz and W. Schnick, Chem. Eur. J., 1997, 3, 249.

13 H. Yamane and F. J. DiSalvo, J. Alloys Compd., 1996, 240, 33.

14 H. Huppertz and W. Schnick, Angew. Chem., Int. Ed. Engl., 1997, 36, 2651 .

15 K. H. Jack, J. Mater. Sci., 1976, 11, 1135.

16 S. Hampshire, Mater. Sci. Technol., 1994, 11, 119.

17 H. Lange, G. Wötting and G. Winter, Angew. Chem., Int. Ed. Engl., 1991, 30, 1579.

18 P. S. Gopalakrishnan and P. S. Lakshminarasimham, J. Mater. Sci. Lett., 1993, 12, 1422.
19 E. I. Givargizov, Curr. Top. Mater. Sci., 1978, 1, 89.

20 G. M. Sheldrick, SHELXTL V5.0 Crystallographic System, Siemens Analytical X-Ray Instruments Inc., Madison, WI, 1994.

21 P. L. Wang, P. E. Werner, A.L. Gao, R. K. Harris and D. P. Thompson, J. Mater. Chem., 1997, 7, 2127.

22 Z. Inoue, M. Mitomo and N. Ii, J. Mater. Sci., 1980, 15, 2915.

23 G. R. Hatfield, B. Li, W. B. Hammond, F. Reidinger and J. Yamanis, J. Mater. Sci., 1990, 25, 4032.

24 M. Woike and W. Jeitschko, Inorg. Chem., 1995, 34, 5105.

25 R. Hoppe, Angew. Chem., Int. Ed. Engl., 1966, 5, 95.

26 R. Hoppe, Angew. Chem., Int. Ed. Engl., 1970, 9, 25.

27 R. Hübenthal, MAPLE, Version 4, Universität Gießen, 1993.

28 N. E. Breese and M. O. Keeffe, Acta Crystallogr., Sect. B, 1991, 47, 192.

29 W. H. Baur, Crystallogr. Rev., 1987, 1, 59.

Paper 8/03900C 